\title{
ANÁLISE DE FÁCIES DA FORMAÇÃO CORUMBATAÍ (GRUPO PASSA DOIS- BACIA DO PARANÁ, NEOPERMIANO), COM VISTAAO EMPREGO NA INDÚSTRIA DE REVESTIMENTO CERÂMICO
}

\author{
SERGIO RICARDO CHRISTOFOLETTI', MARIA MARGARITA TORRES MORENO² \& \\ ALESSANDRO BATEZELLI ${ }^{3}$
}

\begin{abstract}
Resumo As argilas da Formação Corumbataí, unidade Neopermiana da Bacia do Paraná, são consideradas atualmente a maior fonte de matéria-prima para o setor de revestimento cerâmico do país. O presente trabalho teve como objetivo principal, aplicar o conceito de fácies aliado à caracterização mineralógica, química e cerâmica, visando uma nova estratégia para exploração. De acordo com os estudos realizados, foram reconhecidas cinco litofácies (Maciça, laminada, Intercalada I, Intercalada II e Alterada), sendo que estas foram agrupadas em duas grandes Associações (Associação Siltito Argiloso e Associação Siltito Arenoso); estas associações foram plotadas em mapa na escala 1:50.000. Com aplicação desta metodologia é possível melhorar o controle da matéria-prima, reduzindo os custos e perdas, e garantindo um produto de melhor qualidade. A aplicação da geoestatística por meio da análise da Superficie de Tendência foi importante no tratamento dos dados de caracterização cerâmica e química, pois, com os mapas obtidos, foi possivel definir áreas mais favoráveis para a implantação de futuras minas.
\end{abstract}

Palavras Chave: litofácies, cerâmica, Formação Corumbataí, argila

\begin{abstract}
ANALYSES OF CORUMBATAI FORMATION FACIES (PASSA DOIS GROUP-PARANÁ BASIN-NEOPERMIANO) FOR THE USE OF CERAMIC TILE INDUSTRIES. The mud rocks from Corumbatai Formation, Neopermian unity of Paraná Basin, are at the moment, the principal font of raw material for floor tiles industries in Brazil. In this paper we are applied the lithofacies concept, mineralogical and chemical composition data and ceramic characteristics for define exploration places. It was identify five lithofacies (Massive, Laminated, Intercalated I, Intercalated II and Alterated) all they grouped in two associations (sandy siltstone and argillaceous silstone). The data was plotted in map 1:50,000 scale. This method permits get a best control on raw material, consequently better quality and chipper. It was important the statistical method application (Tendency Surface Analysis) for define the probable areas for future exploration.
\end{abstract}

Keywords: lithofacies, ceramic, Corumbatai Formation, clay

INTRODUÇÃ̃O A Bacia do Paraná, entidade geotectônica situada no sudeste da placa Sul-Americana abrange uma área de $1.600 .000 \mathrm{~km}^{2}$, sendo sua maior parte concentrada em território brasileiro (aproximadamente $1.000 .000 \mathrm{~km}^{2}$ ), distribuída nos estados do Rio Grande do Sul, Santa Catarina, Paraná, São Paulo, Mato Grosso do Sul, Mato Grosso, Minas Gerais e Goiás. Segundo Milani (1997), o registro total da Bacia do Paraná inclui estratos que se distribuem do Neo-Ordoviciano (450 Ma) ao Neo-Cretáceo (65 Ma), compondo uma unidade estratigráfica de ordem I que demarca a própria entidade "Bacia do Paraná", como aquele local da superfície terrestre no qual aconteceram sucessivos episódios de subsidência no Fanerozóico, e que permitiram a acumulação e preservação do pacote que se pode observar nela atualmente. Figura 1

As unidades litoestratigráficas da Bacia do Paraná são muito importantes no contexto econômico do Estado de São Paulo, principalmente por abrigarem recursos minerais não metálicos, com destaque para os arenitos da Formação Pirambóia usados na indústria de vidro, as argilas da Formação Corumbataí (alvo de estudo) para a indústria cerâmica, as argilas das Formações Aquidauana e Itararé para a indústria cerâmica estrutural, os calcários para corretivo agrícola da Formação Iratí e os recursos hídricos subterrâneos dos Aqüíferos Guarani da Formação Botucatu.

A Formação Corumbataí (Neo-Permiano) representa uma unidade litoestratigráfica diferenciada na Bacia do Paraná, constituindo uma importante fonte de matéria-prima para a indústria de revestimentos cerâmicos, principalmente na porção central do Estado de São Paulo, na região conhecida como Pólo Cerâmico de Santa Gertrudes.
OBJETIVOS E JUSTIFICATIVAS O trabalho teve por objetivo analisar a faciologia das argilas da Formação Corumbataí, na área de estudo, com o objetivo de propor uma exploração mais racional para a fabricação de revestimentos cerâmicos. Atualmente, a exploração é feita de maneira rudimentar. Notase descaso das mineradoras em realizar estudos que definam as reservas e permitam o conhecimento das características geológicas e tecnológicas destas. O controle das minas atualmente é visual, as argilas são denominadas "taguás" e são classificadas como dura e mole pelas pessoas responsáveis pela mineração, sendo desprezadas as variações laterais e verticais existentes nas matérias-primas.

A proposta deste trabalho foi identificar as litofácies existentes nas minas do Pólo Cerâmico de Santa Gertrudes. Litofácies pode ser definida como uma somatória dos parâmetros básicos de definição de fácies presentes em uma rocha (Selley, 1976). Após a identificação das litofácies, foi realizado o estudo das características químicas, mineralógicas e cerâmicas nas amostras coletadas.

Um outro objetivo deste estudo foi compartimentar estas litofácies em mapa na escala 1:50.000, agrupando-as em duas associações. Esta compartimentação servirá como guia na implantação racional de novas minas, a fim de determinar a matéria-prima mais apropriada para a produção de revestimentos cerâmicos, possibilitando melhora na qualidade da matéria-prima, reduzindo custos e perdas, garantindo assim um produto final ausente de defeitos visuais provenientes das variações das matérias-primas.

O Pólo Cerâmico de Santa Gertrudes produziu 252 milhões

1 - Instituto Geológico-SMA (Secretaria do Meio Ambiente), Avenida Miguel Stefano, 3900, São Paulo-SP, CEP 04301-903- Ảgua Funda e-mail: sergioricardoc@gmail.com

2 - Departamento de Petrologia e Metalogenia (DPM), Avenida 24a $\mathrm{N}^{\circ}$ 1515, CP 178, CEP 13506-900 Bela Vista-Rio Claro e-mail: mmoreno@rc.unesp.br

3 - Instituto de Geociências - Universidade Estadual de Campinas - UNICAMP. Rua João Pandiá Calógeras, 51, e-mail: alessandro.batezelli@gmail.com 


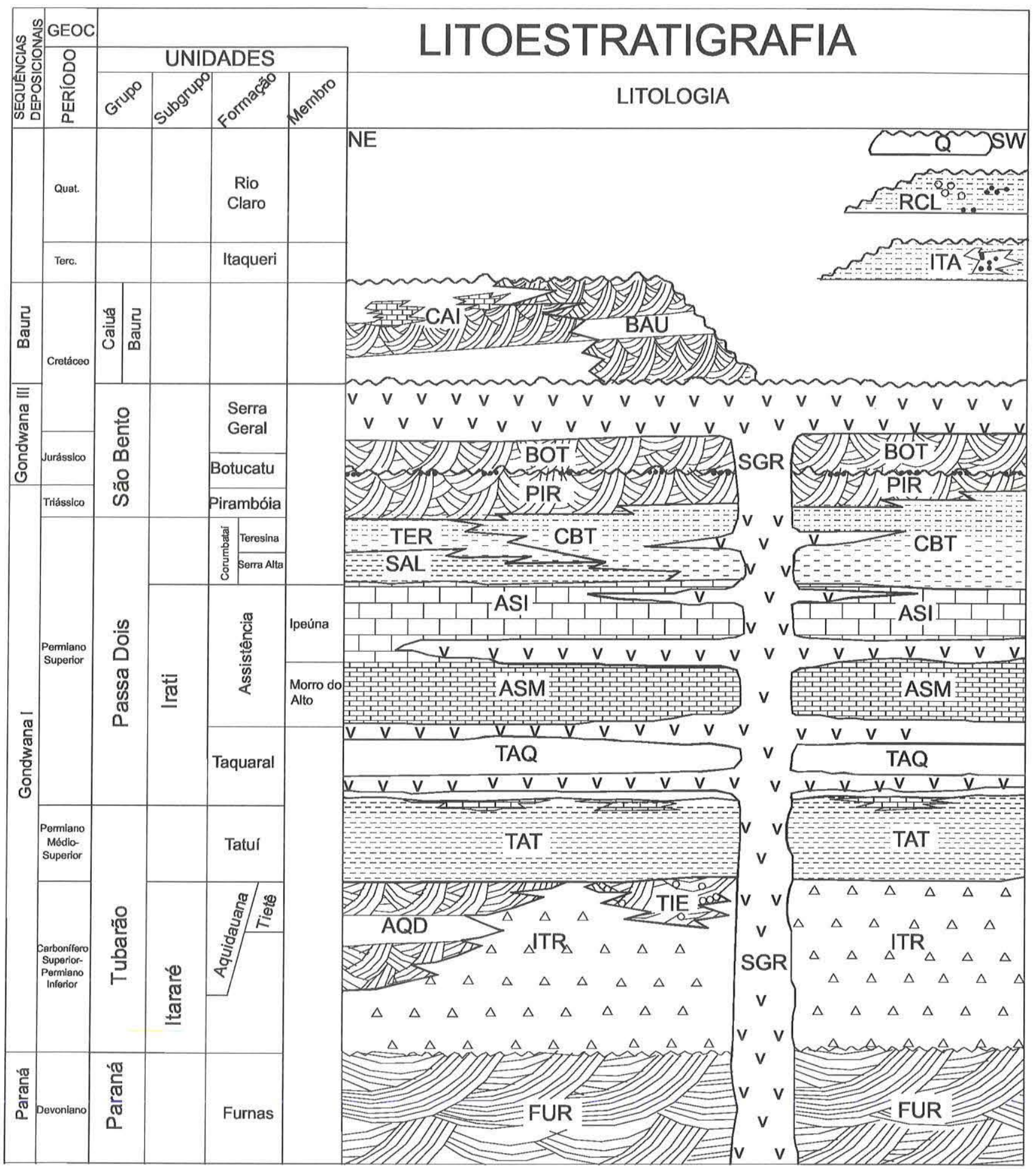

\section{LEGENDA}

$\begin{array}{lll}v_{v} & v & v \\ \end{array}$ Basalto/diabásio

Arenito com estratificações
cruzadas

$\because \%: \because$ Conglomerado

Siltito laminado

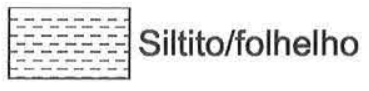

Arenito maciço

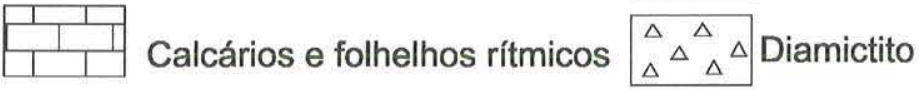

Calcário calcífero

Folhelho

Figura 1. Bacia do Paraná e suas unidades litoestratigráficas no Estado de São Paulo (Montanheiro, 1999). 
de $\mathrm{m}^{2}$ no ano de 2004 , representando $50 \%$ da produção de revestimentos cerâmicos do mercado nacional e $75 \%$ do mercado do Estado de São Paulo (Motta et al. 2004). Atualmente, 42 indústrias pertencentes a este pólo produzem revestimentos da Classe BIIb na Classificação de Revestimentos Cerâmicos, que podem ser considerados como de classe média em termos de qualidade.

FORMAÇÃO CORUMBATAí O termo Corumbataí apareceu pela primeira vez no Relatório da Comissão Geográfica e Geológica de São Paulo, no ano de 1916 para designar os xistos argilosos e betuminosos com fósseis e assim o descreveu Pacheco (1927) que indicou as exposições correntes no Vale do Rio Corumbataí, no Município de Piracicaba, como área tipo. Landim (1970) denominou como Formação Corumbataí às rochas sedimentares essencialmente argilosas de coloração arroxeada ou avermelhada com intercalações de lentes de arenito muito fino, aflorantes no Vale do Rio Corumbataí.

Vários trabalhos clássicos foram desenvolvidos na década de 50 como Mendes (1952), Almeida \& Barbosa (1953); já na década de 70 existem os trabalhos realizados na porção nordeste da Bacia do Paraná (Landim 1970, Soares et al. 1973, e de Scheneider et al. 1974). Porém o trabalho que merece destaque foi realizado por Melo e Souza (1985), que estudou as fácies da Formação Corumbataí e Estrada Nova aflorantes no Estado de São Paulo. Além disto, a autora realizou a reconstrução paleoambiental, e reconheceu a compartimentação da Bacia do Paraná durante o Permiano Superior.

A espessura da Formação Corumbataí, na sua faixa aflorante em território paulista, é da ordem de 130 m, não ultrapassando 60 metros nas proximidades das cidades de Leme e Pirassununga, mas em direção norte ela adelgaça até se anular próximo ao limite com Minas Gerais (Landim, op. cit.). Seu contato subjacente faz-se concordantemente com a Formação Iratí, mas o contato de topo com a Formação Pirambóia se dá por discordância erosiva (Soares et al. 1973, Zalan et al. 1987).

Segundo Landim (1967), esta unidade pode ser dividida em duas seqüências: uma inferior constituída por siltitos cinza escuro a roxo, maciços, exibindo fratura conchóide, e a outra superior, com coloração vermelha arroxeada, caracterizada pela intercalação de argilitos, siltitos, arenitos finos e coquinas. As principais estruturas sedimentares encontradas na Formação Corumbataí, segundo (Scheneider, et al. 1974), são: laminação plano-paralela, laminação flaser, fendas de ressecamento, laminação cruzada, marcas onduladas, estruturas estromatolíticas associadas com calcários oolíticos e, nos corpos arenosos, estratificação cruzada de pequeno porte.

A paleontologia da Formação Corumbataí é composta de lamelibrânquios ou bivalves na forma de moldes silicificados, conchostráceos, ostrácodes, peixes cartilaginosos e ósseos, vegetais principalmente representados por licófitas Lepidodendrales (Lycopodiopsis derbyi), gimnospermas Glossppteridales (Glossopteris sp) e megásporo (Simões \& Fittipaldi, 1992).

Scheneider et al. (op.cit) consideram a parte inferior da Formação Corumbataí como tendo sido depositada em ambiente marinho plataformal de águas profundas em condições redutoras, porém sua porção superior se depositou em águas rasas em condições oxidantes sob influência de marés. Já Melo e Souza (1985) distingue oito fácies e cinco subfácies, que levaram à caracterização de depósitos de alto mar e face de praia (shoreface), e de planície de maré (tidal flat).

LOCALIZAÇÃO DA ÁREA A área de estudo localiza-se na porção centro-sudeste do Estado de São Paulo, abrangendo os municípios de Rio Claro, Santa Gertrudes, Cordeirópolis, Limeira e Araras na região administrativa de Campinas, situandose entre as coordenadas $47^{\circ} 20^{\prime}$ e $47^{\circ} 40^{\prime}$ e de $22^{\circ} 16^{\prime}$ e $22^{\circ} 38^{\prime}$
E/W, das folhas topográficas de Rio Claro (SF- -M-I-4), Araras (SF-23-M-II-3) e Limeira (SF-23-M-IV-1). Figura 2.

MÉTODOS DE TRABALHO O método de trabalho empregado na execução desta pesquisa consistiu das seguintes etapas:

Levantamento geológico básico: nas minas com o objetivo de reconhecer as fácies e associações de fácies, de acordo com os métodos de análise propostos por Miall (1984). Este reconhecimento faciológico foi feito por meio de estudos detalhados na forma de seções colunares em 20 minas, localizadas na área de estudo. Nesta etapa foram coletadas amostras para caracterização em laboratório.

Caracterização cerâmica: após os tratamentos de moagem e peneiramento, as amostras foram prensadas e submetidas a queima na temperatura de $1120^{\circ} \mathrm{C}$. Para a determinação das propriedades tecnológicas foram feitos os ensaios de TRF (tensão de ruptura à flexão), AA (absorção de água), RLQ (retração linear de queima), entre outros. Estes ensaios seguiram as normas ABNT (Associação Brasileira de Normas Técnicas13818- Especificações e métodos de ensaios para Revestimentos Cerâmicos 1997).

Caracterização química: a análise química restringiu-se à identificação e determinação quantitativa dos elementos maiores por Fluorescência de raios X, utilizando-se o aparelho Philips PW 2510.

Caracterização mineralógica: para a identificação das fases mineralógicas existentes, o método utilizado foi a Difratometria de raios X. As amostras foram analisadas na sua constituição total (sem separação granulométrica) e na fração argila. O aparelho para a análise mineralógica foi o Difratômetro Siemens D5000 (velocidade de goniômetro de $3^{\circ}(2 \theta) /$ min e radiação $\left.\mathrm{CoK}\right)$. Utilizou-se a metodologia baseada em Thiry 1974, Brow \& Brindley 1980.

Tratamento estatístico: Análise Estatística Univariada das superficies de tendências e isopletas com o software Surfer 7.0 nos resultados das características cerâmicas e químicas.

RESULTADOS Os resultados encontrados referem-se ao estudo de 20 minas, localizadas na região do Pólo Cerâmico de Santa Gertrudes onde o objetivo principal foi identificar as litofácies presentes em cada uma destas minas, de acordo com os métodos de análise propostos por Miall (1984). Nesta fase de identificação das fácies, foram coletadas 101 amostras que, posteriormente foram analisadas em laboratório.

Características Geológicas $\mathrm{O}$ conceito de fácies tem sido muito discutido na literatura geológica desde a década de 40 por diversos autores (Krumbeim \& Sloss 1963, Walker 1984, Miall 1984 e Reading 1978). Atualmente, o termo fácies é usado tanto para expressar caráter descritivo, como interpretativo de rochas. Do ponto de vista descritivo, os termos litofácies ou biofácies são usados para designar os atributos sedimentares que ajudam na interpretação de processos deposicionais e biológicos.

De acordo com critérios de reconhecimento de fácies, baseados na descrição de afloramentos e de seções nas minas estudadas, as argilas da Formação Corumbataí, na área de estudo, foram classificadas em cinco litofácies: Maciça, Laminada, Intercalada I, Intercalada II e Alterada (Tabela 1). Estas litofácies por apresentarem características similares, foram agrupadas em duas associações de fácies (associação Siltito Argiloso e associação Siltito Arenoso). Figuras 2, 3 e 4.

A associação Siltito Argiloso é representada pelas litofácies 


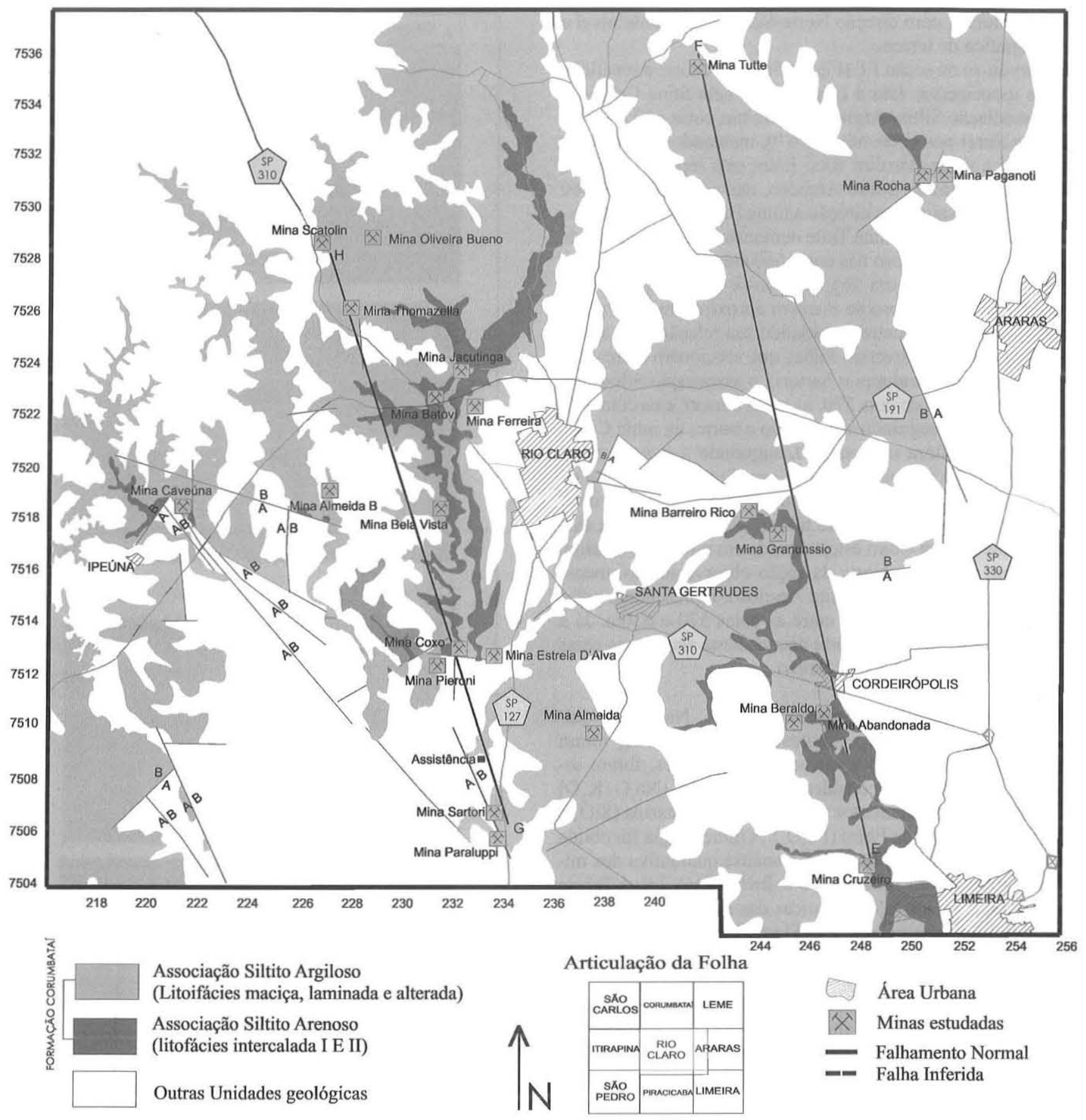

Figura 2. Mapa de localização da área e de litofácies da Formação Corumbatai. In Christofoletti, 2003

Maciça, Laminada e Alterada; sendo a mais representativa na área de estudo. Localiza-se na base da Formação Corumbataí, correspondendo à seqüência inferior de Landim 1967. Possui como estruturas sedimentares principais a laminação plano-paralela incipiente e por vezes maciça, coloração arroxeada/acinzentada, e granulometria argilosa. Nesta associação, dominam os processos de maré de baixa energia ou decantação, gerando, como estruturas sedimentares principais, a estrutura maciça e a laminação plano paralela incipiente dada por areia de granulometria muito fina.

Na maioria das minas estudadas ocorrem, nesta associação, fragmentos fósseis dispersos de conchas e peixes; além destes fragmentos, ocorre um nível denominado "bone bed", composto de $60-70 \%$ de bivalves e ictiofosseis, representado por restos de Elasmobranchii (dentes e espinhos de xenantiformes), Holoce- phaceli (placas dentárias de petalodontes) e Ostheichyes (escamas de crossopterygios, placas dentarias de dipnói e dentes e escamas de paleonisiformes). O restante de 30 a $40 \%$ é constituído de material fosfático, grãos grossos de quartzo e argilitos cimentados com $\mathrm{CaCO}_{3}$. (Toledo et al.1997).

A associação Siltito Arenoso é representada pelas litofácies Intercalada I e II, e se-localiza entre a associação siltito argiloso. Estas litofácies são constituídas por intercalações rítmicas entre siltitos argilosos de cores arroxeados/avermelhados, ora intercalados com siltitos arenosos, ora com arenitos finos. Essas intercalações rítmicas foram geradas por processos de decantação intercalados com processos de maré e tempestades. As estruturas geradas foram lenticular bedding, wave bedding e Mhcs.

A identificação das associações de fácies e seu empilhamento permitiram a correlação das associações de fácies através de 
seções estruturais, com direção Norte-Sul, usando como nível a cota topográfica do terreno.

Observou-se na seção EF (Figura 5a), que ocorre a repetição das duas associações. Isto é comprovado pela mina Cruzeiro, onde a associação Siltito Argiloso ocorre nas cotas 610 até 640 , e volta a ocorrer nas cotas 660 até 670 , mantendo-se constante a Norte, até a mina Barreiro Rico Entre esta repetição, ocorre a associação de fácies Siltito Arenoso, nas cotas 640, até 660 mantendo-se constante em direção a mina Barreiro Rico. No extremo Norte da seção, a mina Tutte demonstra a continuidade da associação Siltito Argiloso nas cotas 660 até 670 .

Na Seção G-H (Figura 5b), observa-se que a espessura da associação Siltito Argiloso se mantém aproximadamente constante (em torno de 60 metros), variando sua relação com a cota topográfica, devido a diversas falhas que seccionam a área. $\mathrm{Na}$ porção Sul (minas Paraluppi e Sartori), a associação Siltito Argiloso ocorre a partir da cota 570, na mina Sartori, e na cota 600 , na mina Paraluppi seguindo em direção a norte, na mina Coxo, essa associação aflora na cota 530, sugerindo a existência de uma zona de falha normal que tenha gerado um abatimento de bloco. Na mina Bela Vista a associação de fácies Siltito Argiloso volta a aflorar nas cotas 570 até $600 \mathrm{~m}$. Esta é mais uma evidencia de que a mina Coxo esteja situada em um bloco abatido. Seguindo em direção a Norte da seção observa-se novamente a ocorrência da associação Siltito Argiloso, representada pelas minas Thomazella e Scatolin, entre as cotas 570 e $630 \mathrm{~m}$. Já a associação Siltito Arenoso ocorre apenas nesta seção, nas cotas 540 até 560, nas minas Coxo e Batoví.

Características químicas e mineralógicas Na análise química por espectrometria de Fluorescência de raios X, foram quantificados a \% de óxidos maiores. Dentre estes, foram selecionados os elementos considerados fundentes $\left(\mathrm{Na}_{2} \mathrm{O}+\mathrm{K}_{2} \mathrm{O}\right)$ e $(\mathrm{CaO}+\mathrm{MgO})$, e os elementos considerados refratários $\left(\mathrm{SiO}_{2} \mathrm{e}\right.$ $\mathrm{Al}_{2} \mathrm{O}_{3}$ ) além do óxido de Ferro $\left(\mathrm{Fe}_{2} \mathrm{O}_{3}\right)$. A mineralogia foi obtida por Difração de raios X por meio da análise qualitativa dos minerais e argilominerais utilizando o software EVA 2.0. A Tabela 2 apresenta as composições químicas das rochas da Formação Corumbataí na área estudada, e a (Figura 6a) ilustra as diferenças químicas destas litofácies.

A análise de Difração de raios X mostrou que o argilomineral predominante é a illita seguida da caulinita, ambos encontrados em todas as litofácies. Também ocorrem com freqüência a montmorilonita e a clorita, presentes nas litofácies Laminada, Intercalada I e Intercalada II. De todos minerais encontrados, o quartzo é o mais representativo, seguido pela albita, calcita, hematita e dolomita. A calcita, dolomita e albita predominam nas litofácies Intercalada I e II. Figura 7

Os valores encontrados nas litofácies são mostrados na Tabela 2. A soma $\left(\mathrm{Na}_{2} \mathrm{O}+\mathrm{K}_{2} \mathrm{O}\right)$ variam de $2,9( \pm 1,3) \%$ para a litofácies Alterada até $4,3( \pm 1,4) \%$ para as litofácies Laminada e Intercalada II. Já a soma $(\mathrm{CaO}+\mathrm{MgO})$, na litofácies Intercalada II atinge valor médio de $5,4( \pm 3,8) \%$. Dentre as amostras coletadas existem algumas que apresentaram altas concentrações, como por exemplo, na litofácies Intercalada II, com 14,7\% de $(\mathrm{CaO}+\mathrm{MgO})$ e na litofácies Maciça com 9,4\% de $\mathrm{Fe}_{2} \mathrm{O}_{3}$. O óxido de silício, $\left(\mathrm{SiO}_{2}\right)$, apresentou valores que variaram de $64,7( \pm 4,0) \%$ até valores de $67,7( \pm 2,5) \%$. O Fe $\mathrm{O}_{3}$ exibe valores médios da ordem de $4,6 \%$ até $5,3 \%$ para a litofácies Laminada. A litofácies Intercalada II foi o que apresentou características mais fundentes e menor conteúdo de refratários, encontrando valores médios de $10,6 \%$ para o $\mathrm{Al}_{2} \mathrm{O}_{3}$ e de $64,8 \%$ para $\mathrm{SiO}_{2}$.

$\mathrm{Na}$ (Figura 6a), as litofácies Maciça, Laminada e Intercalada I apresentaram quantidades semelhantes de fundentes $\left(\mathrm{Na}_{2} \mathrm{O}+\mathrm{K}_{2} \mathrm{O}+\mathrm{CaO}+\mathrm{MgO}\right)$, exceção feita às litofácies Alterada e Intercalada II. A litofácies Alterada ficou empobrecida em fun-
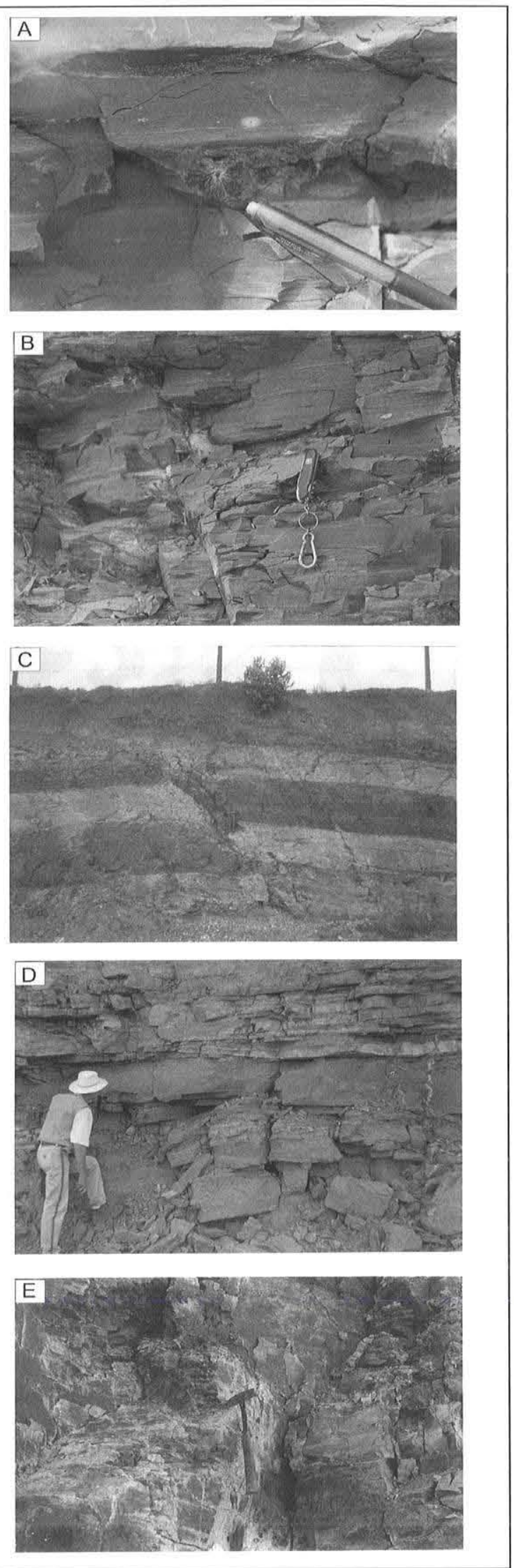

Figura 3-Fotografias das litofácies identificadas em campo.(a) litofácies siltito maciço. Observa-se na porção superior da foto uma camada de bone bed e na porção basal uma feição rosácea dada por óxido de manganês, (b) litofácies laminada, (c) litofácies intercalada I. Falha inversa de direção WNW-ESE com rejeito aproximado de 1 metro. (d) siltito intercalado II, e (f) litofácies alterada. 


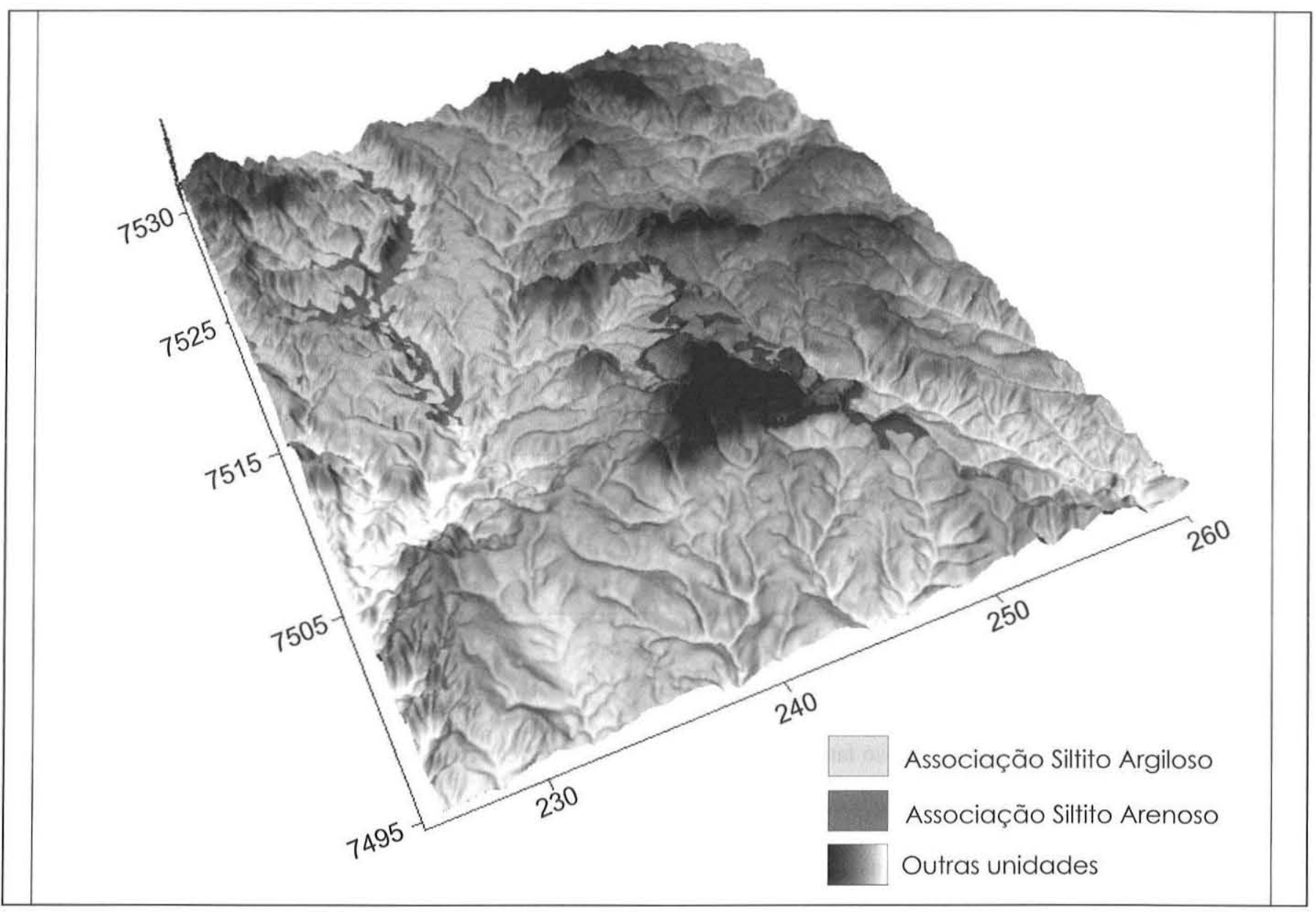

Figura 4. Modelo digital 3D geológico da área de estudo mostrando as associações identificadas.

Tabela 1. Principais Litofácies cerâmicas

\section{Litofácies}

Cerâmica

\section{Características}

Litologia

Cor

granulometria

estrutura

Associação Siltito Argiloso

\begin{tabular}{lllll}
\hline Maciça & Siltito & $\begin{array}{l}\text { Arroxeado, vermelho, verde, } \\
\text { amarelo, acinzentado. }\end{array}$ & Argiloso a médio & Maciço \\
\hline Laminada & Siltito & $\begin{array}{l}\text { Arroxeado, vermelho, verde, } \\
\text { amarelo, acinzentado. }\end{array}$ & Argiloso a médio & $\begin{array}{l}\text { Laminação plano-paralela } \\
\text { incipiente }\end{array}$ \\
\hline Alterada & Siltito & $\begin{array}{l}\text { Esbranquiçado, avermelhado, } \\
\text { arroxeado, acinzentado. }\end{array}$ & Argiloso & Sem estruturas \\
\hline
\end{tabular}

Associação Siltito Arenoso

\begin{tabular}{llll}
\hline \multirow{2}{*}{ Intercalada I } & Siltito & Arroxeado e vermelho & Arenoso a médio \\
\cline { 2 - 4 } & Siltito & Arroxeado e vermelho & Ritmito \\
\hline \multirow{2}{*}{ Intercalada II } & Siltito & Arroxeado e vermelho & $\begin{array}{l}\text { Argiloso, Arenoso ou } \\
\text { médio }\end{array}$ \\
\cline { 2 - 4 } & Arenito & Branco & $\begin{array}{l}\text { Muito fino, médio e } \\
\text { grosso }\end{array}$ \\
\hline
\end{tabular}




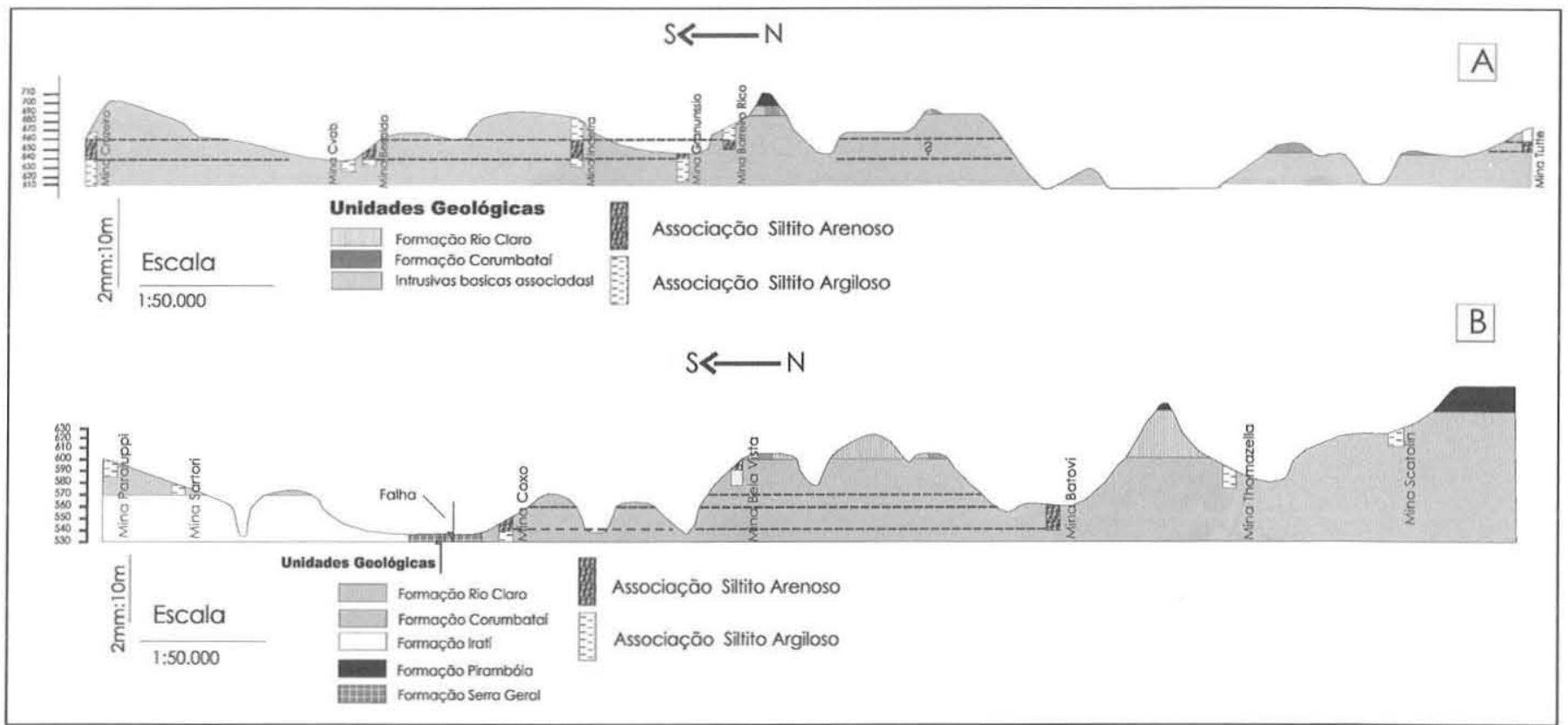

Figura 5. Seções estruturais $G-H(A)$ e $E-F(B)$.

dentes $\left(\mathrm{Na}_{2} \mathrm{O}+\mathrm{K}_{2} \mathrm{O}+\mathrm{CaO}+\mathrm{MgO}\right)$ devido ao fator intempérico; e a litofácies Intercalada II separou-se das outras pelo fato de conter maiores quantidades de $\mathrm{CaCO}_{3}$, representado pelo valor de Perda ao Fogo (LOI). Este fato é comprovado pelas características geológicas, químicas e mineralógicas desta litofácies.

Características Cerâmicas Os resultados cerâmicos foram obtidos em laboratório, seguindo a Norma NBR 13818 (ABNT, 1997). A Tabela 3 apresenta as propriedades cerâmicas obtidas para as rochas da Formação Corumbataí, indicando o valor médio, o Desvio Padrão, o valor máximo e mínimo, em 101 amostras estudadas. A Figura $6 \mathrm{~b}$ ilustra as diferenças das propriedades cerâmicas entre estas amostras.

Os valores médios obtidos de tensão de ruptura á flexão de 200 e $300 \mathrm{Kgf} / \mathrm{cm}^{2}$ e absorção de água entre (6,2 e 12\%), nas amostras estudadas, possibilitaram enquadrar as litofácies cerâmicas dentro do Grupo BIIb, segundo a Classificação de Revestimentos Cerâmicos (que estabelece valores entre 180-300Kgf/ $\mathrm{cm}^{2}$ para a tensão de ruptura à flexão e de 6-10\% de absorção de água). Porém, alguns valores de absorção de água ficaram acima de $10 \%$ para as litofácies Intercalada I, II e para a Alterada. Os resultados cerâmicos mostraram que as litofácies maciça e laminada são as mais adequadas para a produção de revestimentos cerâmicos pelos valores de absorção de água e de tensão de ruptura à flexão. A característica fundente destas litofácies foi fator primordial para o melhor desempenho no processo cerâmico.

De acordo com os valores de retração de queima, os maiores resultados foram encontrados nas litofácies Maciça e Alterada, com valores de $8.1 \%$. Os valores da massa específica aparente (MEA) apresentaram uma pequena variação, ficando seus valores entre $1,91 \mathrm{~g} / \mathrm{cm}^{3}$ na litofácies Intercalada II, até valores de $2,08 \mathrm{~g} / \mathrm{cm}^{3}$ na litofácies Laminada.

Nos ensaios cerâmicos, como demonstrado na Figura 6b, a granulometria foi dominante no comportamento cerâmico das litofácies, separando as litofácies mais argilosas (Maciça e Laminada) das outras três litofácies. O critério principal desta separação foi o teor de carbonatos (calcita e dolomita), encontrado na litofácies Intercalada II com valor de 5,4\% de $(\mathrm{CaO}+\mathrm{MgO}) \mathrm{A}$ litofácies Intercalada I localiza-se na região com alta concentração de AA (Absorção de Água), pelo fato desta possuir porcen- tagens mais elevadas de $\mathrm{SiO}_{2}$ em relação às demais, comprovado pela Difração de raios X, e suportado pela análise química.

Análise Estatística Multivariada Os mapas resultantes da utilização do software Surfer 7.0 revelaram importantes resultados na distribuição das médias, tanto dos elementos maiores das minas como no comportamento cerâmico (Figura 8). Estes mapas foram obtidos a partir da soma das espessuras das litofácies encontradas nas minas estudadas. Estes resultados julgam-se necessários na busca da matéria-prima mais adequada ao processo cerâmico. Dentre os mapas confeccionados, destacam-se dois grupos: $\mathrm{O}$ primeiro representa os valores médios dos elementos maiores $\left(\mathrm{SiO}_{2}, \mathrm{Al}_{2} \mathrm{O}_{3}, \mathrm{MgO}+\mathrm{CaO}, \mathrm{Na}_{2} \mathrm{O}+\mathrm{K}_{2} \mathrm{O}\right)$ nas amostras das minas, o outro grupo é representado pelos valores médios das variáveis cerâmicas absorção de água (AA) e tensão de ruptura à flexão (TRF), sendo estes dois parâmetros os classificatórios em termos de qualidade.

$\mathrm{O}$ teor de $\mathrm{SiO}_{2}$ mostrou uma faixa de tendência de direção sul-sudoeste, chegando a concentrações de 65 até $71 \%$ dadas pelas minas Sartori, Paraluppe, Coxo, Pieroni e Almeida. Este alto teor de sílica advém do quartzo, dos feldspatos e dos argilominerais illita e caulinita (Figura 8a).

A maior concentração de alumínio ocorre em um núcleo individualizado, representado pela mina Beraldo, com valores acima de $18 \%$ de $\mathrm{Al}_{2} \mathrm{O}_{3}$. Na maioria das minas os valores são considerados médios a altos, sendo estes de 15 até $16,5 \%$ de $\mathrm{Al}_{2} \mathrm{O}_{3}$, representados por dois núcleos principais, localizados na porção centro-noroeste da área (minas Oliveira Bueno, Scatolin, Thomazella e Ferreira), e na porção Centro-Sudoeste (minas Coxo, Almeida B, Estrela D'Alva e Pieroni). Os valores médios variaram de 10 a $18 \%$ de $\mathrm{Al}_{2} \mathrm{O}_{3}$ (Figura 8 b).

$\mathrm{O}$ teor de $\mathrm{SiO}_{2}$ bem como de $\mathrm{Al}_{2} \mathrm{O}_{3}$ são importantes para a indústria cerâmica, pois estes constituem elementos refratários, e em excesso, podem prejudicar a sinterização durante o processo de queima.

As maiores concentrações de $\left(\mathrm{Na}_{2} \mathrm{O}+\mathrm{K}_{2} \mathrm{O}\right)$ ocorrem em quatro núcleos principais, distribuidos por toda a área: um núcleo à Leste, um a Oeste, um ao Norte e um ao Sudeste. A Leste na mina Granunssio, Oeste, na mina Caviúna, a Norte, na mina Rocha, e Sudeste na mina Cruzeiro; os valores da soma $\left(\mathrm{Na}_{2} \mathrm{O}+\mathrm{K}_{2} \mathrm{O}\right)$ 
Tabela 2. Elementos maiores. Obs. DESVPAD = Desvio Padrão, MA-VALOR (Valor máximo) e MI-VALOR (Valor mínimo).

\begin{tabular}{|c|c|c|c|c|c|}
\hline \multirow{2}{*}{$\begin{array}{l}\text { Litofácies } \\
\text { Cerâmicas }\end{array}$} & \multicolumn{5}{|c|}{ Elementos Maiores em \% } \\
\hline & $\mathrm{Na}_{2} \mathrm{O}+\mathrm{K}_{2} \mathrm{O}$ & $\mathrm{CaO}+\mathrm{MgO}$ & $\mathrm{SiO}_{2}$ & $\mathrm{Al}_{2} \mathrm{O}_{3}$ & $\mathrm{Fe}_{2} \mathrm{O}_{3}$ \\
\hline \multicolumn{6}{|l|}{ Maciça } \\
\hline MÉDIA & 3,9 & 2,6 & 67,7 & 14,1 & 5,8 \\
\hline DESVPAD & 1.3 & 1.6 & 2.5 & 1.8 & 1.6 \\
\hline MA-VALOR & 5,7 & 3,7 & 71,0 & 17,7 & 9,4 \\
\hline MI-VALOR & 2,0 & 0,8 & 64,0 & 11,3 & 3,1 \\
\hline \multicolumn{6}{|l|}{ Laminada } \\
\hline MÉDIA & 4,2 & 3,0 & 67,0 & 14,7 & 5,3 \\
\hline DESVPAD & 1.3 & 1.5 & 2.4 & 1.6 & 0.7 \\
\hline MA-VALOR & 6,2 & 7,9 & 73,5 & 18,9 & 7,2 \\
\hline MI-VALOR & 2,1 & 1,2 & 58,3 & 10,2 & 4,0 \\
\hline \multicolumn{6}{|c|}{ Intercalada I } \\
\hline MÉDIA & 3,5 & 2,9 & 67,4 & 15,0 & 4,6 \\
\hline DESVPAD & 1.5 & 3.6 & 3.5 & 2.5 & 1.2 \\
\hline MA-VALOR & 6,2 & 14,7 & 71,0 & 18,7 & 6,3 \\
\hline MI-VALOR & 1,3 & 1,1 & 56,0 & 10,2 & 2,4 \\
\hline \multicolumn{6}{|c|}{ Intercalada II } \\
\hline MÉDIA & 4,3 & 5,4 & 64,4 & 14,0 & 5,0 \\
\hline DESVPAD & 1.4 & 3.8 & 3.10 & 3.4 & 1.3 \\
\hline MA-VALOR & 6,4 & 14,7 & 71,2 & 18,7 & 7,2 \\
\hline MI-VALOR & 1,2 & 2,0 & 56,0 & 10,2 & 2,9 \\
\hline \multicolumn{6}{|l|}{ Alterada } \\
\hline MÉDIA & 2,9 & 1,8 & 64,8 & 17 & 6,0 \\
\hline DESVPAD & 1.2 & 0.5 & 4,0 & 2.7 & 1.4 \\
\hline MA-VALOR & 5,1 & 3,0 & 69,0 & 23 & 8,0 \\
\hline MI-VALOR & 1,3 & 1,1 & 56,4 & 14,6 & 3,8 \\
\hline
\end{tabular}

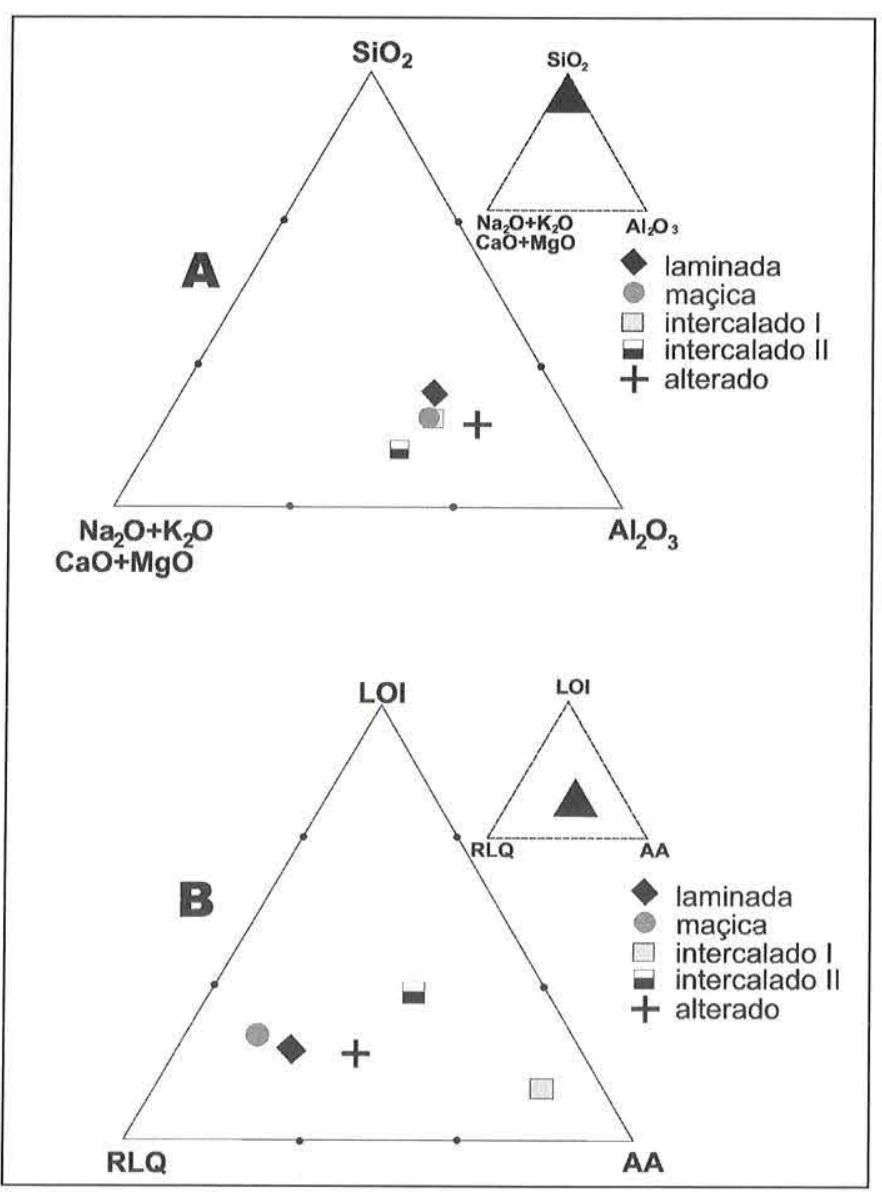

Figura 6. Diagrama ternário para as litofácies cerâmicas em função dos elementos maiores (A) $\mathrm{SiO}_{2}, \mathrm{Al}_{2} \mathrm{O}_{3}, \mathrm{Na}_{2} \mathrm{O}+\mathrm{K}_{2} \mathrm{O}$, $\mathrm{CaO}+\mathrm{MgO}$ e (B) diagrama ternário em função da $\mathrm{AA}=$ absorção de água, $R L Q=$ retração linear de queima e $L O I=$ perda ao fogo.
Tabela 3. Resultados Cerâmicos. MA-VALOR (Valor máximo) e MI-VALOR (Valor minimo); TRF=tensão de ruptura à flexão, $A A=$ absorção de água, $P A=$ porosidade aparente, $R L Q=$ retração linear de queima, MEA=massa especifica aparente e $L O I=$ perda ao fogo.

\begin{tabular}{|c|c|c|c|c|c|c|}
\hline \multirow{2}{*}{$\begin{array}{l}\text { Litofácies } \\
\text { Cerâmicas }\end{array}$} & \multicolumn{6}{|c|}{ Quanto a Cerâmica } \\
\hline & TRF & AA & PA & RLQ & MEA & LOI \\
\hline \multicolumn{7}{|l|}{ Maciça } \\
\hline MÉDIA & 261 & 7,8 & 14,6 & 8,1 & 2,1 & 5,4 \\
\hline DESVPAD & 59.1 & 6.2 & 9.6 & 1.8 & 0.3 & 2.5 \\
\hline MA-VALOR & 358,5 & 21,5 & 29,2 & 10,9 & 2,4 & 11,7 \\
\hline MI-VALOR & 193,3 & 1,2 & 0,3 & 5,7 & 1,4 & 2,9 \\
\hline \multicolumn{7}{|l|}{ Laminada } \\
\hline MÉDIA & 265,2 & 6,5 & 11,6 & 7,2 & 2,1 & 4,9 \\
\hline DESVPAD & 86.2 & 4.9 & 8.3 & 2.6 & 0.2 & 2.5 \\
\hline MA-VALOR & 418 & 16 & 29,3 & 12,1 & 2,6 & 13,8 \\
\hline MI-VALOR & 155,2 & 0,5 & 1,0 & 0,8 & 1,8 & 2,6 \\
\hline \multicolumn{7}{|l|}{ Intercalada I } \\
\hline MÉDIA & 209 & 12 & 21,5 & 5,5 & 1,9 & 5,3 \\
\hline DESVPAD & 72.7 & 6.6 & 10.1 & 2.5 & 0.2 & 2.0 \\
\hline MA-VALOR & 352,2 & 23,9 & 36,9 & 8,70 & 2,1 & 10,9 \\
\hline MI-VALOR & 151,9 & 1,9 & 4,2 & 0,4 & 1,6 & 2,7 \\
\hline \multicolumn{7}{|l|}{ Intercalada II } \\
\hline MÉDIA & 258,9 & 10,0 & 18,8 & 7,0 & 1,9 & 7,0 \\
\hline DESVPAD & 103.8 & 7.4 & 11.7 & 2.6 & 0.3 & 4.4 \\
\hline MA-VALOR & 423,3 & 27,9 & 43,3 & 10,7 & 2,2 & 18,2 \\
\hline MI-VALOR & 133,2 & 0,2 & 0,4 & 1,5 & 1,1 & 2,0 \\
\hline \multicolumn{7}{|l|}{ Alterada } \\
\hline MÉDIA & 233,5 & 9,7 & 19,6 & 8,1 & 2,0 & 6,0 \\
\hline DESVPAD & 74.9 & 5.3 & 8.9 & 2.6 & 0.2 & 1.0 \\
\hline MA-VALOR & 375,3 & 7,8 & 33 & 13,1 & 2,3 & 7,3 \\
\hline MI-VALOR & 115,6 & 4,4 & 13,1 & 4,7 & 1,8 & 4,8 \\
\hline
\end{tabular}

atingem $6 \%$. Estes elementos são responsáveis pelo processo de sinterização da peça a ser queimada, e advêm principalmente do argilomineral illita e do mineral feldspato (Figura 8c).

Já os teores médios da soma $(\mathrm{MgO}+\mathrm{CaO})$ atingem seu máximo de $12 \%$. Sua maior concentração ocorre na porção nordeste da área, representada pelas minas Tutte, Rocha e Paganotti. Um outro núcleo mais isolado ocorre na porção centro oeste da área na mina Batoví com valor de $12 \%$ de $\mathrm{CaO}$. Geralmente, os valores médios de Cão, em toda a área não ultrapassam $6 \%$. O carbonato, quando encontrado na forma disseminada, ou seja, na matriz com porcentagens de 5-10\%, tem grande importância na sinterização, pois ele aumenta a resistência mecânica (Figura 8d).

A alta porcentagem de absorção de água (AA) ocorre em dois núcleos. O primeiro núcleo, localizado na porção CentroOeste, é o mais significativo, sendo representado pelas minas Batovi, Ferreira, Bela Vista e o segundo encontra-se a nordeste da área (minas Paganoti e Rocha). Observando-se os valores de absorção de água (Figura. 8e), nota-se claramente, ao comparar com os mapas de álcalis (Figura 8c), que existe uma dependência da absorção de água com os teores de fundentes. Quase todos os máximos da Figura 8e correspondem aos mínimos da Figura 8c, ou seja, quanto maior a fundência (sinterização), menor será a absorção de água.

Os valores elevados de tensão de ruptura à flexão ocorrem em um grande núcleo, abrangendo as porções Leste e Sudeste da área, sendo este representado pelas minas: Batoví, Estrela D' Alva, Granunssio, Almeida, Barreiro Rico e Beraldo com valores acima de $33 \mathrm{~N} / \mathrm{mm}^{2}$ (Figura 8f). Na maioria dos casos as minas que apresentam maiores valores de Tensão de Ruptura à Flexão equivalem àquelas com maiores valores de elementos fundentes . Por outro lado, onde ocorrem as maiores concentrações do elemento $\mathrm{SiO}_{2}$, os valores de tensão de ruptura á flexão decrescem progressivamente, isto é verificado nas minas Rocha, Thomazella, Ferreira e Caviúna. 

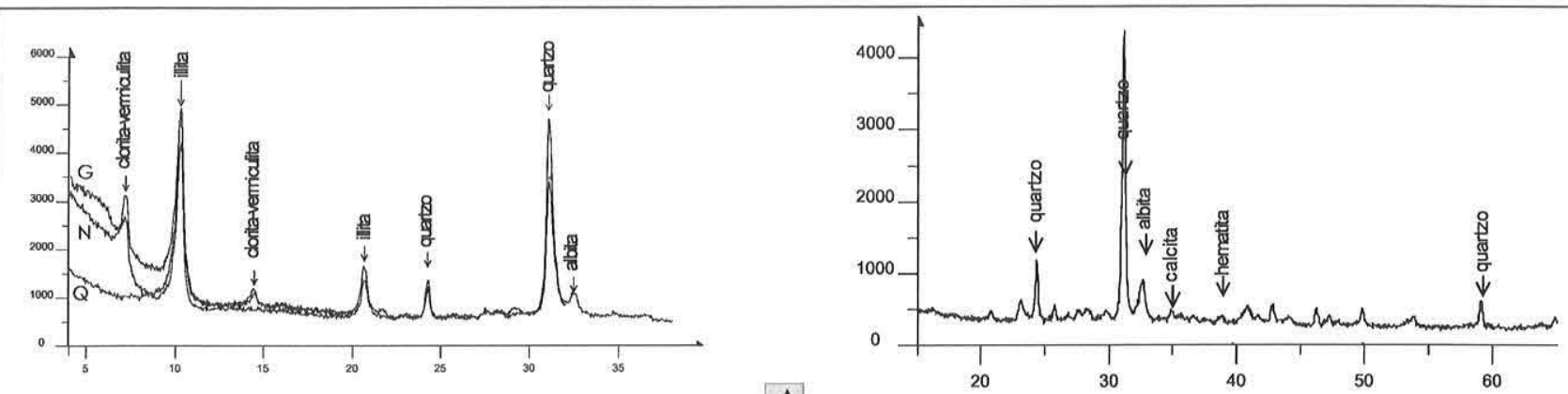

A
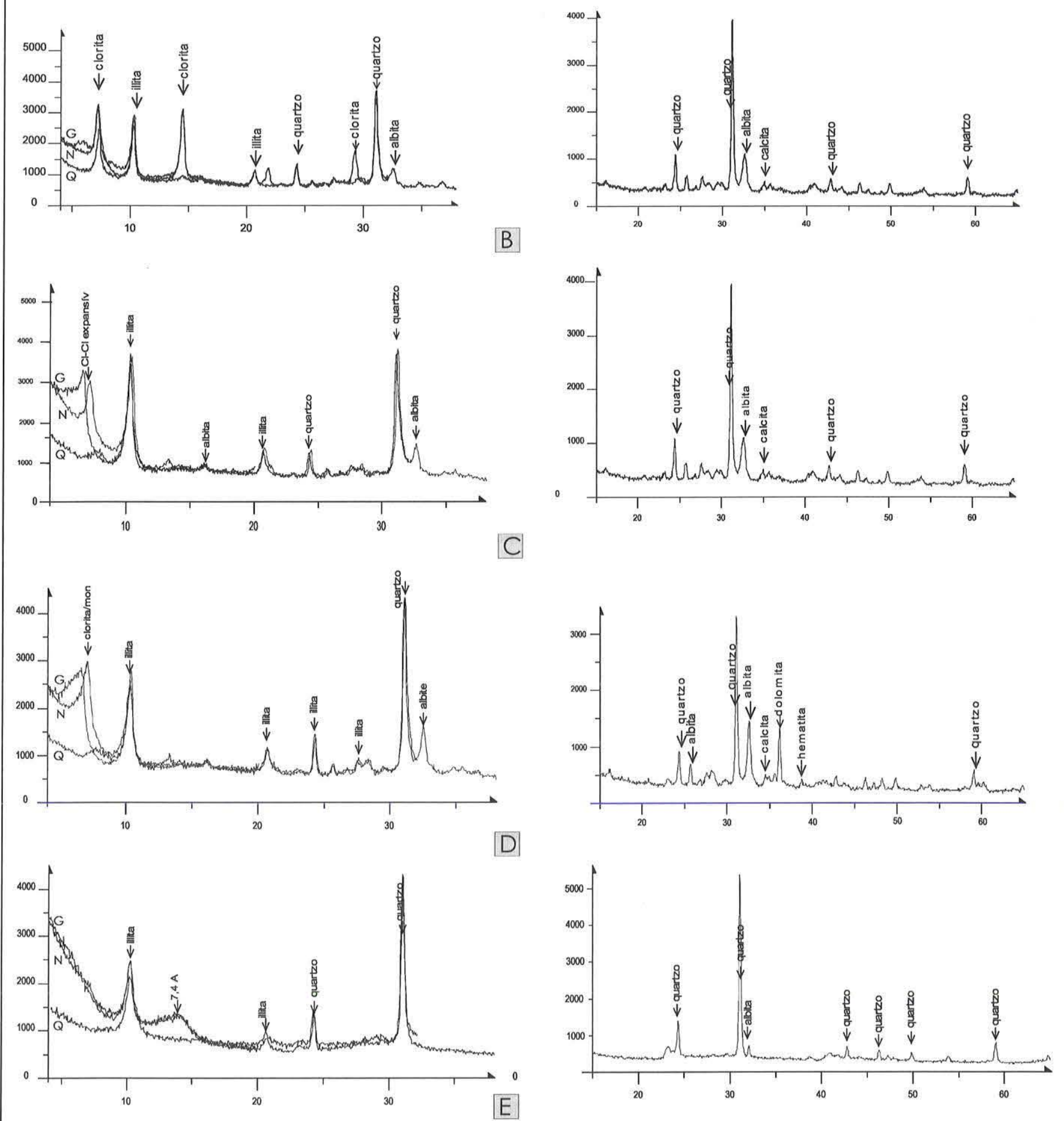

Figura 7. Difratograma de raios X (Amostra Total e Fração Argila). (A)=litofácies maciça, $(B)=$ alterada, $(C)=l a m i n a d a$, $(D)=$ intercalada I e $(E)=$ intercalada II. 

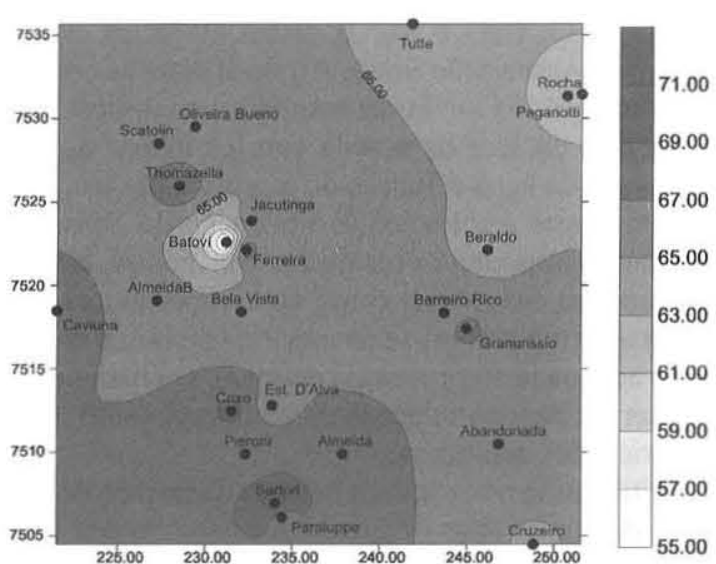

(A)

$\mathrm{SiO}_{2}$

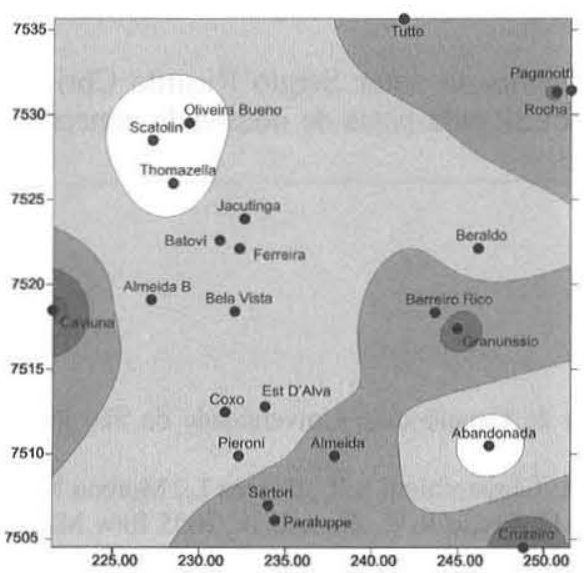

(C)

$$
\mathrm{Na}_{2} \mathrm{O}+\mathrm{K}_{2} \mathrm{O}
$$

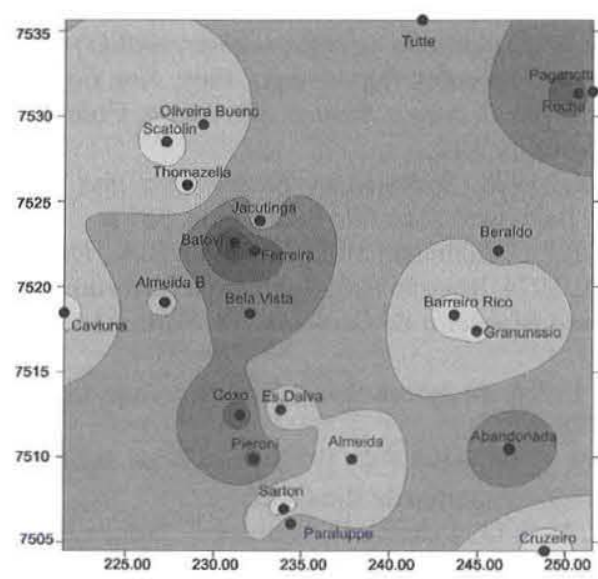

(E)

AA
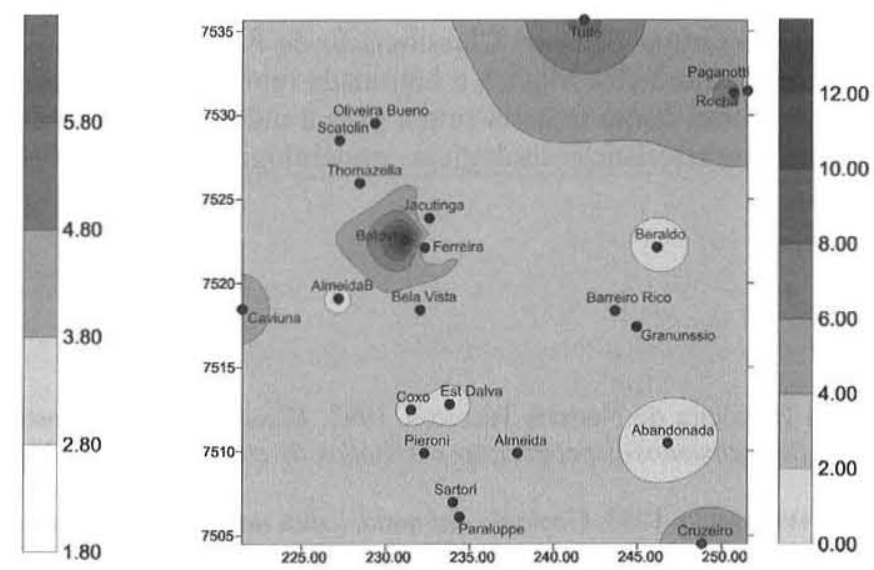

(D)
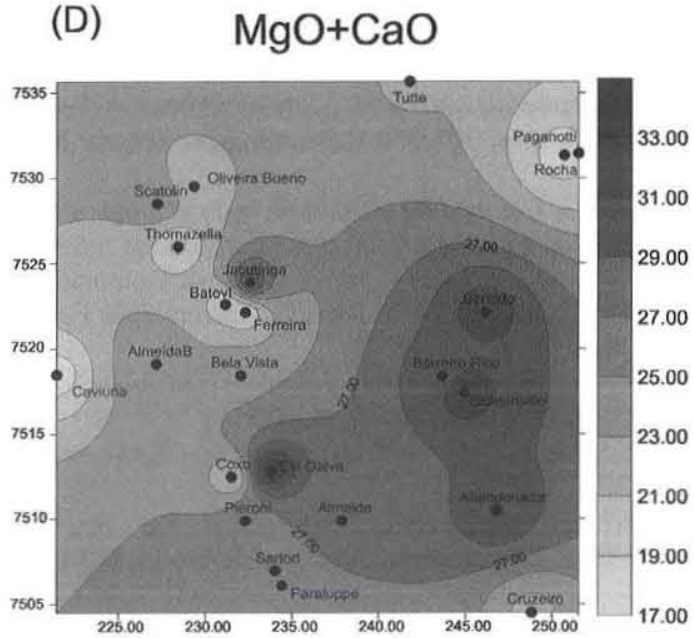

$(\mathrm{F})$

TRF

Figura 8. Mapa de isovalores dos valores médios das minas com relação aos elementos maiores: (a) $\mathrm{SiO}_{2}$, (b) $\mathrm{Al}_{2} \mathrm{O}_{3}$, (c) $\mathrm{Na}_{2} \mathrm{O}+\mathrm{K}_{2} \mathrm{O}$ (d) $\mathrm{MgO}+\mathrm{CaO}$, em \%, e com relação aos ensaios cerâmicos: (e) $A A=$ absorção de água em \% e (f) TRF=módulo de ruptura a flexão em Nmm2.

CONCLUSÕES As argilas da Formação Corumbataí podem ser classificadas em cinco litofácies cerâmicas Maciça, Laminada, Intercalda I, Intercalda II e Alterada. Estas litofácies, por apresentarem características similares, foram agrupadas em duas associações: associação Siltito Argiloso e associação Siltito Arenoso. A associação Siltito Argiloso é a mais representativa na área de estudo e é composta pelas litofácies maciça, laminada e alterada, enquanto a associação Siltito Arenoso é representada pelas litofácies Intercalada I e II. A partir das seções estruturais, foi possível visualizar o provável posicionamento topográfico destas associações, permitindo um direcionamento de estudos mais detalhados nas áreas alvos. Observou-se que as minas estão controladas por feições estruturais, sendo estes, lineamentos de drenagens, associados às zonas de falhas, que individualizaram blocos altos e baixos (grabens e horsts).

Dentre os minerais encontrados, o quartzo é o mais repre- 
sentativo, seguido pela albita, calcita, hematita e dolomita. $\mathrm{O}$ argilomineral predominante é a illita, sendo este o principal agente responsável pela sinterização da peça durante a queima; outros minerais como o feldspato do tipo albita e a hematita também auxiliam. Outros argilominerais ocorrem com freqüência, tais como a montmorilonita e a clorita, presentes nas litofácies laminada, Intercalada I e Intercalada II. Os minerais calcita, dolomita e albita predominam nas litofácies Intercalada I e II.

As argilas da Formação Corumbataí, na área de estudo podem ser consideradas argilas com teores médios de fundentes, atingindo valores que variam de $3,9-4,3 \%$ para a soma de $\left(\mathrm{Na}_{2} \mathrm{O}+\mathrm{K}_{2} \mathrm{O}\right)$, e valores de $2.6-5.4 \%$ para $(\mathrm{CaO}+\mathrm{MgO})$ nas litofácies cerầmicas.

De acordo com as características tecnológicas, todas as fácies da Formação Corumbataí na área de estudo são potencialmente aproveitáveis como matéria-prima para a indústria de revestimento cerâmico, uma vez que os resultados obtidos nos ensaios cerâmicos possibilitaram enquadrar as referidas matérias-primas dentro do Grupo BIIb, na Classificação de Revestimento Cerâmicos. As litofácies Maciça e Laminada representam as mais interessantes como matéria-prima para a indústria cerâmica, pela suas características litológicas, mineralógicas e por apresentarem maiores quantidades de elementos fundentes $\left(\mathrm{Na}_{2} \mathrm{O}, \mathrm{K}_{2} \mathrm{O}, \mathrm{CaO}\right.$ e $\left.\mathrm{MgO}\right)$. Estas litofácies estão localizadas dentro da Associação Siltito Argiloso entre as cotas 530 e $600 \mathrm{~m}$ e apresentam os melhores resultados cerâmicos na porção leste-sudeste da área de acordo com os mapas de isosvalores de Absorção de água e Tensão de ruptura a flexão.

Os mapas resultantes da utilização do Software Surfer 7.0 revelaram importantes resultados nas médias, tanto dos elementos maiores das minas, como no comportamento cerâmico. Os resultados mostraram-se necessários na busca da matéria-prima mais adequada ao processo cerâmico. $\mathrm{O}$ cruzamento destes mapas serviu para correlações do comportamento químico com as propriedades cerâmicas.

Utilizando os conceitos básicos de análise de fácies, foi possível definir os tipos de minérios existentes nas minas e a partir daí, dar subsídios para um planejamento a exploração com o objetivo de reduzir os custos e as perdas decorrentes das variações da matéria-prima e garantir um produto final de qualidade.

Agradecimentos. O autor Sergio Ricardo Christofoletti agradece à FAPESP pela bolsa de doutorado concedida. Processo. 99/00364-3.

\section{Referências}

ABNT Associação Brasileira de Normas Técnicas. 1997. Placas Cerâmicas Para Revestimentos-Especificação e Métodos de ensaios, $78 \mathrm{p}$.

Almeida F.F.M. \& Barbosa O. 1953. Geologia das quadriculas de Piracicaba e Rio Claro, Estado de São Paulo. Boletim DNPM, Rio de Janeiro, n.143, p.1-96.

Brow G. \& Brindley G.W. 1980. X Ray diffraction procedures for clay mineral identification. In: G.W. Brindley \& G. Brown (Ed.) Crystal structures of clay minerals and their X-Ray identification. London, Mineralogical Society, p. 305-360 (Mineralogical Society Monograph $\mathrm{n}^{\circ} 5$ ).

Christofoletti S.R. 2003. Um modelo de classificação geológico-tecnológica das argilas da Formação Corumbatai utilizadas nas induistrias do Pólo Cerâmico de Santa Gertrudes. Tese de Doutoramento, Instituto de Geociências e Ciências Exatas, Universidade Estadual Paulista, Rio Claro, 307p.

Comissão Geográfica e Geológica. 1916. Relatório da Comissão Geográfica e Geológica do Estado de São Paulo.

Krumbein W.C. \& Sloss L.L. 1963. Stratigraphy and Sedimentation, $660 \mathrm{p}$.

Landim P.M.B. 1967. O Grupo Passa Dois na Bacia do Rio Corumbatai (SP). Rio de Janeiro, Departamento Nacional de Produção Mineral, Boletim 252.

Landim P.M.B. 1970. O Grupo Passa Dois (P) na bacia do Rio Corumbatai (SP). Rio de Janeiro, Boletim da Divisão de Geologia e Minas-Departamento Nacional de Produção Mineral, n. 252, p. 1-103.

Mendes J.C. 1952b. A Formação Corumbatai na região do Rio Corumbatai, estratigrafia e descrição dos lamelibrânquios. FFCL. Geologia, São Paulo, Boletim n ${ }^{\circ}$.145, p.1-19.

Melo e Souza S.H. 1985. Fácies sedimentares das Formações Estrada Nova e Corumbatai no Estado de São Paulo. Dissertação de Mestrado, Instituto de Geociências, Universidade de São Paulo, São Paulo, 142p.

Miall A.D. 1984. Principles of Sedimentary Basin Analysis. First Edition. New York, Springer-Verlag, 490p.

Milani E.J. 1997 Evolução Tectono-Estratigráfica da Bacia do Paranáe seu relacionamento com a Geodinâmica Fanerozóica do Gondwana Sul-Ocidental. Tese de Doutoramento, Universidade Federal do Rio Grande do Sul, Porto Alegre, 225 p.

Montanheiro T.J. 1999. Prospecção e Caracterização de pozolanas na Bacia do Paraná, Estado de São Paulo. Tese de Doutoramento,
Instituto de Geociências, Universidade de São Paulo, São Paulo, 226p.

Motta J.F.M., Christofoletti S.R., Garcez L., Moreno M.M.T., Chucierato G., Florencio R.V., Zanardo A. 2005 Raw Materials for Ceramic Tiles in the Santa Gertrudes Pole, Brazil. Interceram Review, 54(3):90-94.

Pacheco J.A.1927. Relatório elucidativo do esboço geológico da região compreendida entre o meridiano 4 Rio Itararé e os paralelos 2334 e 24 38. In: Exploração da região compreendida pelas folhas topográficas de Sorocaba, Itapetininga, Bury, Sete Barras, Capão Bonito, Ribeirão Branco e Itararé. São Paulo, Comissão Geográfica e Geológica, p. 9-12.

Reading H.G. 1978. Sedimentary Enviroments and Fácies. 1st edn, Oxford, Balckwell Scientific Publication, 557 p.

Scheneider R.L., Muhlmann H.E., Medeiros R.A., Daemon R.F., Nogueira A. 1974. Revisão Estratigráfica da Bacia do Paraná. In: SBG, Congresso Brasileiro de Geologia, 28, Porto Alegre, Anais, v.1, p. 41-65.

Selley R.C. 1976a. An Introdution to Sedimentology. London, Academic Press, $408 \mathrm{p}$.

Simões M.G. \& Fittipaldi F.C. 1992. Fósseis da região de Rio Claro. Arquivo do município de Rio Claro.

Soares P.C., Nelli O., Penalva F., Wernick E., Souza A., Castro P.R.M. 1973. Geologia do Nordeste do Estado de São Paulo. In: SBG, Congresso Brasileiro de Geologia, 27, Aracaju, Anais, v.1, p. 243-256.

Thiry M. 1974. Techinique de préparation des minéraux argileux en vue de L "analyse aux rayomus $x$. Strasbourg, France, Centre National de la Reacherche Scientifique, Centre de Sedimentologie et Géochimie de la Surface, 25p.

Toledo C.E.V., Masson M.R., Bertin R.J. 1997. Lithosedimentological analysis of a bone-bed with vertebrate remains from Corumbatai Formation (Upper Permian) near Rio Claro City, State of S. Paulo (Brazil). In: SBP, Congresso Brasileiro de Paleontologia, 15, S. Pedro, Boletim de Resumos, p.159.

Walker R.G. 1984. Facies model. 2nd ed., Geosciences, Canada. Reprint Series 1,317 p. 